\title{
Phytochemical Screening, Antioxidant, Antiulcer, Anti-Inflammatory and Analgesic Activity of the Aqueous Extract of Angelica archangelica
}

\author{
Walid Mamache 1,2,a,*, Abderrahim Benslama ${ }^{3, \mathrm{~b}}$, Fatima Benchikh ${ }^{2,4, c}$, Hassiba Benabdellah ${ }^{2,4, d}$, \\ Sabira Lassas, ${ }^{4, e}$, Hind Amira ${ }^{4, f}$, Smain Amira ${ }^{2,4, g}$ \\ ${ }^{1}$ Department of Biochemistry, Faculty of Nature and Life Sciences, University of Ferhat Abbas Setif-1-, Setif, Algeria. \\ ${ }^{2}$ Laboratory of Applied Phytotherapy to Chronic Diseases, University of Ferhat Abbas Setif -1-, Setif, Algeria. \\ ${ }^{3}$ Department of Biochemistry and Microbiology, University of M'sila, Faculty of Sciences, M'sila, Algeria \\ ${ }^{4}$ Department of Biology and animal physiology, Faculty of Nature and Life Sciences, University of Ferhat Abbas Setif-1-, Setif, Algeria. \\ *Corresponding author \\ A R T I C L E I N F O \\ A B S T R A C T \\ Research Article \\ Received : 01/01/2022 \\ Accepted : 08/01/2022 \\ Keywords: \\ Phytchemical \\ Antioxidant activity \\ Anti-flammatory \\ Analgesic effect \\ Anti-ulcer activity

\begin{abstract}
The objective of this study is to evaluate the antioxidant, antiulcer, anti-inflammatory and analgesic activity of the aqueous extract of Angelica archangelica L., a medicinal plant of the traditional pharmacopoeia of Algeria. The aqueous extract showed a large amount of total polyphenols, tannins, chlorophyll a, b, carotenoids and a small amount of flavonoids with values of $80.16 \pm 14.3$ $\mathrm{mg} \mathrm{EAG} / \mathrm{g}$ of extract, $3.12 \pm 2.01 \mathrm{mg}$ EQ/g of extract, $226.10 \pm 4.50 \mathrm{mg}$ EAT/g of extract, $6.10 \pm 50.62$, $12.00 \pm 31.53$ and $1.78 \pm 0.40 \mu \mathrm{g} / \mathrm{mL}$ respectively. In addition, the aqueous extract of $A$. archangelica showed a high ability to trap DPPH radical in with IC50 at $16.9 \pm 2.03 \mu \mathrm{g} / \mathrm{mL}$. However, the aqueous extract has a great protective effect against $\beta$-carotene degradation at $91.98 \pm 0.64 \%$ after 24 hours and significant ferrous ion chelation activity at $46.2 \pm 1.53 \mu \mathrm{g} / \mathrm{mL}$. Furthermore, the antiinflammatory activity was studied according to the protein denaturation inhibition method and, according to the results obtained, the extract of A. archangelica at concentrations of $250,500 \mu \mathrm{g} / \mathrm{mL}$ and $1 \mathrm{mg} / \mathrm{mL}$ have ahigh antiinflammatory activity whose inhibition percentages are $78.85 \pm 5.31 \%$, $86.65 \pm 2.70 \%$ and $89.89 \pm 0.58 \%$ respectively. The analgesic effect of the aqueous extract of $A$. archangelica, showed that the concentration $400 \mathrm{mg} / \mathrm{mL}$ has a greet abdominal cramps inhibitory effect in comparison with the concentration $200 \mathrm{mg} / \mathrm{mL}$ with a percentage of $98.28 \%$. The antiulcer effect of the aqueous extract of $A$. archangelica was evaluated by the $70 \%$ ethanol-induced ulcer test. The results obtained reveal that the aqueous extract 200 and $400 \mathrm{mg} / \mathrm{mL}$ exerted a considerable effect of protecting the stomach at $86.55 \pm 3.51 \%$ and $82.82 \pm 2.18 \%$ respectively.
\end{abstract}

b@abderrahim.benslama@univ-msila.dz d@hassiba.benab@gmail.com f@hind.ami@gmail.com
(D) http://orcid.org/0000-0002-8626-6269 (iD) http://orcid.org/0000-0001-8046-1066 (iD http://orcid.org/0000-0003-3368-5256

\section{Introduction}

The action of eating and drinking provides our body with the elements necessary for maintenance of life and health, Food will be varied, sufficient, adapted to the needs of each individual, in correlation with his activity (Akgul et al., 2020; Kina et al., 2021). From food, the body makes raw material that will play the role of structural materials and energy source of our organization (Sevindik et al., 2017; Uysal et al., 2021). Nutritional status also depends on digestion by the digestive system which digests the food and absorbs the elements that it transforms in the blood or lymph by making them cross its mucous membrane and eliminate waste (Korkmaz et al., 2021; Pehlivan et al., 2021).
Any agent that breaks the continuity of the gelatinous barrier formed by the mucosa causes inflammation of the stomach lining; this condition is called gastritis a persistent damage to the underlying tissue can lead to peptic ulcers, or more specifically gastric ulcers (Sipponen and Maaroos, 2015). This condition affects about $10 \%$ of adults in countries Westerners with a prevalence of $2 \%$ and an incidence of $0.03 \%$. Gastric ulcer was also common in men than in women. The average age of onset of ulcers is 65 (exceptional before 40 years) (Karila-Cohen et al., 2005). The aetiologies of gastric ulcer were multiple: factors hereditary in 15 to $50 \%$ with a predominance of blood groups A, syndromes genetic (multiple endocrine neoplasias 
type 1), psychological factors (stress, stay in intensive care), environmental factors (tobacco, alcohol, coffee) and medication (salicylates, NSAIDs and AIS) (Mustafa et al., 2015; Ommurugan and Rao, 2019). It is currently believed that Helicobacter pylori is present with a prevalence of more than $60 \%$ in patients with a gastric ulcer and more than $70 \%$ in those with antral gastritis. This prevalence also clearly increases with age (Karila-Cohen et al., 2005).

This disease, easy to contract and difficult to cure, has serious repercussions on the health of the individual and can even lead to death. Its treatment is sometimes difficult, according to the depth of the ulcer. Treatment with modern medicine is sometimes expensive, which constitutes a handicap for the patient (Barkun and Leontiadis, 2010; Ommurugan and Rao, 2019). For those who have the means to do it, they develop sometimes a reluctance towards the disease, which is added to the side effects of medications. In Algeria, several plants are used to treat diseases inflammatory, especially gastric ulcer (Bouasla and Bouasla, 2017; Bouzabata, 2017). Among these plants, Angelica archangelica $\mathrm{L}$.

A. archangelica commonly known as Angelica is a biennial or perennial herbaceous medicinal plant, aromatic characteristics of the Apiaceae family. European, distributed in mid-mountain regions of Europe and Asia (Chauhan et al., 2016), this plant is also widespread in Algeria (Bouzabata, 2017). Preferred growing media are moist, nutritious soil which can be easily removed from the roots after harvest, and is not sensitive to temperatures below $0{ }^{\circ} \mathrm{C}$. The normal life cycle of $A$. archangelica is completed in three years, but sometimes, when the seedlings are well developed, it can be achieved in just two years (Kylin, 2010).

This genus has been used for centuries in traditional medicine for the treatment of a variety of illnesses, including influenza, cough, and inflammation (Rajtar et al., 2017). Angelica (A. archangelica) has real antibacterial, antifungal, antioxidant, anti-inflammatory, antiviral, anticonvulsant, sedative, diuretic, immunological and vasodilating properties, It would also relieve certain disorders such as: anemia, insufficient appetite, respiratory problem (asthma), digestion (gastric acidity, gastric ulcer, bloating, aerophagia, vomiting, etc.), male sexual fatigue, hepatism (Lacoste, 2003). In this cntexte the objectives of our work are: the phytochemical study of the aqueous extract of $A$. archangelica and the evaluation of the antioxidant, anti-inflammatory and analgesic activities of the extract.

\section{Materials and Methods}

\section{Materials}

The angelica plant (A. archangelica) used in this study was purchased from an herbalist from Setif, Algeria. The plant was powdered and stored until use.

Albino-type mice, averaging $25 \mathrm{~g}$, were used to study the biological activity of the aqueous extract in vivo. The latter come from the breeding centers of the Pasteur Institute in Algiers. The experiment was carried out at the animal facility of the University of Setif 1 . The mice were raised in conditions favorable to their growth and development, with a light cycle of 12 hours per day and free access to food and water.
All the products used in this study come from Sigma (Paris, France). Carbo methyl cellulose (CMC 1.5\%), acetic acid $\left(\mathrm{CH}_{3} \mathrm{COH}\right)$, Methanol, ethanol, chloroform, linoleic acid (C18H30O2), gallic acid and tannic acid. The chemical reagents are: 2,2'-diphenyl-1-picryl hydrazyl (DPPH), trichloride aluminum $\left(\mathrm{AlCl}_{3}\right)$, Folin - Ciocalteu, Sodium bicarbonate $\left(\mathrm{Na}_{2} \mathrm{CO}_{3}\right)$, Sodium chloride $(\mathrm{NaCl})$, Quercetin, Tween 40, $\beta$ Carotene $\left(\mathrm{C}_{40} \mathrm{H}_{56}\right)$ and Butylhydroxytoluene (BHT).

\section{Methods}

The angelica plant was crushed using a grinder to obtain a powder. A quantity of $30 \mathrm{~g}$ of this powder was boiled in 1 $\mathrm{L}$ of water for 10 minutes and allowed to cool. When the decoction period was over, the homogenate obtained was filtered through the muslin, and vigorously squeezing everything in order to extract as much liquid as possible. The filtrate obtained was subjected to further filtration through filter paper, and poured into plates, then dried in an oven at $38^{\circ} \mathrm{C}$ (Perera et al., 2008). The extract obtained was then stored in a cold place at $4^{\circ} \mathrm{C}$ in a protected bottle, in order to avoid any degradation of the molecules by light.

The extraction yield (\%) (extractable components) expressed on dry weight basis of pant materiel was calculated from the following equation: Yield $(\mathrm{g} / 100 \mathrm{~g})=$ $(\mathrm{W} 1 \times 100) / \mathrm{W} 2$ where $\mathrm{W} 1$ is the weight of the extract residue obtained after solvent evaporation and W2 is the weight of pant materiel used in the extraction.

\section{Phytochemical Analysis}

\section{Total polyphenols}

The determination of the total polyphenols was carried out with the colorimetric reagent Folin Ciocalteu. This reagent consists of a mixture of phosphotungstic acid $\left(\mathrm{H}_{3} \mathrm{PW}_{12} \mathrm{O}_{40}\right)$ and phosphomolybdic acid $\left(\mathrm{H}_{3} \mathrm{PM}_{12} \mathrm{O}_{40}\right)$. This reagent is reduced upon oxidation of phenols to a mixture of greenish blue oxide of tungsten and molybdenum which has maximum absorption at $765 \mathrm{~nm}$ (Li et al., 2007). $500 \mu \mathrm{l}$ of Folin-Ciocalteu reagent (diluted 10 times in distilled water) are added to $100 \mu \mathrm{L}$ of extract or standard solution of gallic acid. After $4 \mathrm{~min}, 400 \mu \mathrm{L}$ of sodium carbonate solution $\left(\mathrm{Na}_{2} \mathrm{CO}_{3}\right)$ with a concentration of $75 \mathrm{mg} / \mathrm{mL}$ are added to the reaction mixture. After an incubation of 1 hour 30 minutes at room temperature and in the dark, the absorbance is read at $765 \mathrm{~nm}$ using a spectrophotometer. The concentration of total polyphenols in the methanolic extract is calculated from the regression equation of the calibration range established with gallic acid and the results were expressed in micrograms of equivalent of gallic acid per milligram of dry extract ( $\mu \mathrm{g} \mathrm{EAG} / \mathrm{mg} \mathrm{E})$.

\section{Flavonoids}

Aluminum trichloride $\left(\mathrm{AlCl}_{3}\right)$ method was used to quantify flavonoids in the extract to be assayed (Benslama and Harrar, 2016). A volume of $500 \mu \mathrm{L}$ of the extract diluted in water and of different concentration of quercetin in methanol was added to $500 \mu \mathrm{L}$ of the $\mathrm{AlCl}_{3}$ solution $(2 \%)$. After $10 \mathrm{~min}$ of incubation at room temperature and in the dark, the absorbances are measured by the spectrophotometer at $430 \mathrm{~nm}$. The concentration of flavonoids in the methanolic extract was calculated from the regression equation of the calibration range established with quercetin and expressed in micrograms of quercetin equivalent per milligram of extract ( $\mu \mathrm{g} \mathrm{EQ} / \mathrm{mg} \mathrm{E}$ ). 


\section{Tannins}

To determine the tannins present in the extract, $1 \mathrm{~mL}$ of hemolyzed bovine blood (absorbance $=1.6$ ) was mixed with $1 \mathrm{~mL}$ of extract and left to stand for $10 \mathrm{~min}$. The absorbance of the supernatant ( $4000 \mathrm{rpm}$ for $10 \mathrm{~min}$ ) was measured at $576 \mathrm{~nm}$ using a spectrophotometer against a white solution (Gharzouli et al., 2002). The calibration curve is constructed with tannic acid at different concentrations. The precipitation efficiency of the solutions tested is expressed in micrograms of tannic acid equivalent per milligram of extract ( $\mu \mathrm{g}$ EAT / mg of extract).

Total chlorophylls and carotenoids

To determine the total chlorophylls and carotenoids in the extract, $1 \mathrm{mg}$ of extract was dissolved in $1 \mathrm{~mL}$ of distilled water (Lichtenthaler and Wellburn, 1983). The absorbance was measured by a spectrophotometer at different wavelengths $(450 \mathrm{~nm}, 645 \mathrm{~nm}, 663 \mathrm{~nm})$. The results were expressed in micrograms per milliliter ( $\mu \mathrm{g} / \mathrm{mL})$ using the following formulas:

$$
\begin{array}{ll}
\text { Chlorophyll a } & =12.7 \times \text { A } 663-2.69 \times \text { A } 645 . \\
\text { Chlorophyll b } & =22.9 \times \text { A } 645-4.68 \times \text { A } 663 . \\
\text { Total chlorophyll } & =20.2 \times \text { A } 645+8.02 \times \text { A } 663 . \\
\text { T carotenoids } & =4.07 \times \text { A } 450-[(0.0435 \times \text { Chlorophyll } \\
& \text { a) }+(0.367 \times \text { Chlorophyll b })] .
\end{array}
$$

\section{The Antioxidant Capacity}

\section{$D P P H$ radical scavenging}

The antioxidant capacity of the extract was estimated by using the DPPH radical scavenging test according to Benslama et al. (2017). In this test, the antioxidants reduce the diphenyl picryl hydrazyl (DPPH) having a purple color to a yellow compound, the color intensity of which of DPPH is inversely proportional to the capacity of the antioxidants present in the medium. The assessment of antioxidant capacity is achieved as follows. $1250 \mu \mathrm{L}$ of a methanolic solution of DPPH $(0.04 \%)$ was mixed with 50 $\mu \mathrm{L}$ of the plant extract or standard antioxidants (acid gallic) at different concentrations. The resulting mixture was then incubated away from the light at room temperature for 30 minutes. Absorbance was measured at $517 \mathrm{~nm}$ (Shekhar and Anju, 2014). The percentage inhibition (I\%) is calculated according to the next formula:

$$
\operatorname{RSA}(\%)=\left[\left(\mathrm{A}_{\mathrm{C}}-\mathrm{A}_{\mathrm{S}}\right) / \mathrm{A}_{\mathrm{C}}\right] \times 100
$$

where RSA is Radical-scavenging activity, $A_{C}$ is the absorbance of control and $A_{S}$ is the absorbance of sample. The data were presented as half maximal effective concentrations $\left(\mathrm{IC}_{50}\right)$, i.e. the concentration of the extract that is necessary to scavenge $50 \%$ of the DPPH radicals.

Beta-carotene ( $\beta$-carotene) bleaching test

The oxidation of linoleic acid generates peroxide radicals, these free radicals will subsequently oxidize $\beta$ carotene causing the disappearance of its red color, which is followed spectrophotometrically at $490 \mathrm{~nm}$. However, the presence of an antioxidant could neutralize free radicals derived from linoleic acid and therefore prevent the oxidation and bleaching of $\beta$ carotene (Kartal et al., 2007). This test was carried out as follows: $0.7 \mathrm{mg}$ of $\beta$-carotene were dissolved in $1 \mathrm{~mL}$ of chloroform. The resulting solution was placed in a flask containing $25 \mu \mathrm{L}$ of linoleic acid and $200 \mathrm{mg}$ of Tween 40. After evaporation of the chloroform, $100 \mathrm{~mL}$ of distilled water saturated with oxygen $\left(\mathrm{H}_{2} \mathrm{O}_{2}\right)$ was added with vigorous stirring. From this new solution $2.5 \mathrm{~mL}$ are transferred into tubes and $350 \mu \mathrm{L}$ of the extract $(2 \mathrm{mg} / \mathrm{mL})$ and of the control BHT, methanol, distilled water was added. The absorbance was immediately measured at $490 \mathrm{~nm}$. Other readings are measured at different time intervals ( $1 \mathrm{~h}, 2 \mathrm{~h}, 4 \mathrm{~h}$ and $24 \mathrm{~h}$ ).

Chelation power on Ferrous $(\mathrm{Fe} 2+)$ Ions

The chelating power of the aqueous extract of $A$. archangelica on ferrous $\left(\mathrm{Fe}^{2+}\right)$ ions was carried according to (Decker and Welch, 1990). A volume of $50 \mu \mathrm{L}$ of $\mathrm{FeCl}_{2}$ $(0.6 \mathrm{mM})$ is added to a volume of $250 \mu \mathrm{L}$ of the extract solution and $450 \mu \mathrm{L}$ of methanol. After stirring, a volume of $50 \mu \mathrm{L}$ of ferrozine is added to the mixture. Everything is incubated for 10 minutes at room temperature and in the dark. The absorbances are read using a spectrophotometer at $562 \mathrm{~nm}$. EDTA was used as a standard for chelation. The percentage of iron chelation was determined according to the following formula:

$$
\% \text { chelation }=\left(A_{C}-A_{E}\right) / A_{C} \times 100
$$

where $A_{C}$ is the absorbance of control and $A_{S}$ is the absorbance with the extract. The data were presented as half maximal effective concentrations $\left(\mathrm{IC}_{50}\right)$, i.e. the concentration of the extract that is necessary to cheat $50 \%$ of the DPPH radicals.

in vitro Anti-inflammatory activity

The in vitro anti-inflammatory activity of extract was determined using the method of denaturation of albumin by heat. A quantity of $500 \mu \mathrm{L}$ of the extract or at different concentrations were added to $500 \mu \mathrm{L}$ of the egg albumin $0.2 \%$ (in Tris- $\mathrm{HCl} 50 \mathrm{mM}, \mathrm{pH}$ 6.6). After stirring, the solutions obtained are placed in an oven at $28{ }^{\circ} \mathrm{C}$ for 15 min. then are incubated in a water bath for $10 \mathrm{~min}\left(70^{\circ} \mathrm{C}\right)$. Turbidity was measured at $660 \mathrm{~nm}$ using a spectrophotometer against a blank (Padmanabhan and Jangle, 2012). The non-steroidal anti-inflammatory drug diclofenac was used as a standard anti-inflammatory agent.

\section{Analgesic Effect}

Before each experiment, mice are placed in individual cages thoroughly wire mesh to avoid coprophagia, and are deprived of their food for 12 to 18 hours, but have plenty of water until one hour before the experiment.

The measurement of the analgesic effect was based on the oral administration of $120 \mu \mathrm{L}(200 \mathrm{mg} / \mathrm{kg}$ and 400 $\mathrm{mg} / \mathrm{kg}$ ) of the plant extract. One hour later, $120 \mu \mathrm{L}$ of acetic acid was gently injected intraperitoneally. Then the mouse was left to stand for $5 \mathrm{~min}$. Afterwards, the mouse was monitored for $25 \mathrm{~min}$ and the number of abnormal contractions is calculated (Atta and Alkofahi, 1998).

\section{Anti-ulcer Activity}

The anti-ulcer activity f extract was carried out described method of mucosal damage injury induced by oral administration of the agent ulcerogenic (ethanol) one hour after administration of extract solutions (Gharzouli et al., 1999). The aqueous extract of $A$. archangelica at doses of 200 and $400 \mathrm{mg} / \mathrm{kg}$ was administered orally $(125 \mu \mathrm{L} /$ mouse) one hour before the force-feeding of $125 \mu \mathrm{L}$ of ethanol. Mice in the negative control group received $1.5 \%$ 
CMC by the same route in addition to oral administration of ethanol but mice in the positive control received $5 \mathrm{mg} / \mathrm{kg}$ ranitidine in addition to oral administration of ethanol. 30 minutes later, the mice are sacrificed by cervical dislocation. After a ventromedial laparotomy, the stomach was excised, then opened according to the greater curvature and washed with water and spread on a plate to determine the surface of the lesions using software Image J 1.5.

\section{Statistical Analysis}

The results of different experiments are expressed as mean \pm SD (standard deviation) for in vitro tests and mean \pm SEM (mean standard deviation) for in vivo tests. The different $\mathrm{IC}_{50}$ values for the in vitro test are calculated using the Graph pad prism 7 software according to the log (concentration) vs Normalization (absorbance) method. To compare the different values, the analysis of variance (one way ANOVA) was performed followed by the Tukey test (multiple comparison). The difference is considered statistically significant at the risk of $5 \%(\mathrm{P}<0.05)$.

\section{Results and Discussion}

\section{Phytochemical Screening}

The plant parts were extracted using the decoction method, and gives a yield of $20.86 \%$. This yield decreases between $9.8 \%$ and $11.88 \%$ during extraction using $95 \%$ methanol at 9.8\% (Kumar and Bhat, 2012; Kumar et al., 2012). This difference can be attributed to the method of the extraction (Perera et al., 2008).

The determination of total polyphenols by the Folinciocalteu method makes it possible to observe that there is a correlation between the absorbance and the concentration of gallic acid (Tabel 1). The polyphenol assay results show that the aqueous extract of the leaves of A. archangelica contains a total polyphenol content of $80.16 \pm 14.3 \mathrm{mg}$ EAG/g of extract.

The quantitative determination of total flavonoids by the $\mathrm{AlCl}_{3}$ method in using quercetin as a standard, shows that absorbance increases with increasing concentration (Tabel 1). The result of the assay indicates that the aqueous extract contains an amount of flavonoids of $3.12 \pm 2.014 \mathrm{mg}$ $\mathrm{EQ} / \mathrm{g}$ E. The quantification of the tannins present in the aqueous extract of $A$. archangelica using the hemoglobin precipitation method showed that the extract contains $226.1 \pm 4.5 \mathrm{mg}$ EAT/g E (Tabel 1).

The quantification of chlorophylls a, b and carotenoid, present in the aqueous extract of the A. archangelica, using the method of Lichtenthaler (1983), showed that the extract contains total chlorophyll a, b and carotenoid of $6.10 \pm 50.62, \quad 12.00 \pm 31.53$ and $1.78 \pm 0.40 \mu \mathrm{g} / \mathrm{mL}$ respectively. Different studies show that different extracts from different parts of the A. archangelica contains polyphenols and flavonoids. However, the aqueous extract of plant has the highest content (Kumar et al., 2011). For different types of pigments, our results show that the content of chlorophyll a, b and carotenoids in A. A. archangelica are higher compared to that of turkie (Lobiuc et al., 2012). The comparison of our data with the published literature is rather difficult because variations have observed for the total phenolic content that could be attributed to the different varieties Angelica's solvent, extraction temperature and technique thus employed different parts used (Kumar and Bhat, 2012; Kumar et al., 2011). However the variation in different pigment contents may result from the influence of the harvest season which is affected by the period of fluoridation and fruit formation (Lobiuc et al., 2012).

\section{Antioxidant Activity}

The anti-free radical activity was carried out using DPPH method. 1-picrylhydrazyl (DPPH) which is a frequently used method for its simplicity. This method was based on the reduction of a methanolic solution of DPPH in the presence of an antioxidant which gives a hydrogen or an electron, the non-radical form DPPH-H was formed (Benslama et al., 2021, 2016). The inhibition of DPPH radical discoloration is a function of the concentration of the extract used and the control gallic acid (reference antioxidant). The antioxidant activity of the extract was expressed as IC50. The aqueous extract of A. archangelica presents an $\mathrm{IC}_{50}$ of $16.9 \pm 2.03 \mu \mathrm{g} / \mathrm{mL}$ and $1.07 \pm 0.007 \mu \mathrm{g}$ $\mathrm{mL}$ for the standard (Figure 1).

The chelating activity of ferrous iron was measured by inhibition of formation of $\mathrm{Fe}^{2+}$-ferrozine complex after incubation of $A$. archangelica extract with $\mathrm{Fe}^{2+}$ according to the method of Decker and Welch (1990). Ferrozine can quantitatively form complexes with $\mathrm{Fe}^{2+}$. However, in the presence of chelating agents, the formation of the complex is disturbed so that the color of the complex is diminished. The measurement of the reduction in color, therefore, allows the estimation of the activity of chelation of the coexisting chelating agent. The divalent ferrous ion plays an important role as catalysts of oxidative processes, leading to the formation of superoxide radicals and hydroxyl anions by Fenton reactions. Chelation of ferrous ions $\left(\mathrm{Fe}^{2+}\right)$ can make Significant antioxidant effects by delaying metal catalyzed oxidation. In this test our extract shows a chelation activity of $46.2 \pm 1.53 \mu \mathrm{g} / \mathrm{mL}$ (Figure 2).

The $\beta$-carotene bleaching mechanism is a radical mediated phenomenon free resulting from hydroperoxides formed from linoleic acid, these free radicals will subsequently oxidize the $\beta$-carotene, thereby causing the disappearance of its red color, which is followed spectrophotometrically at $490 \mathrm{~nm}$. However, the presence of an antioxidant could neutralize radicals derived from linoleic acid and / or inhibit oxidation thus preventing bleaching of $\beta$-carotene. The kinetics of the activity of the aqueous extract of $A$. archangelica and BHT, methanol, water for a time interval between 1 hour to 24 hours presented in the figure (fig. 20). According to the results, a very significant anti-lipid peroxidation activity (at $24 \mathrm{~h}$ ) was obtained with the aqueous extract and BHT $91.98 \pm 0.64 \%, 99.52 \pm 5.82 \%$ respectively.

Table 1. Phytochemical screening of the aqueous extract of A. archangelica.

\begin{tabular}{l|l}
\hline \multicolumn{1}{c|}{ Properties } & \multicolumn{1}{c}{ Value } \\
\hline Yield & $20.86 \%$ \\
TPC $(\mu \mathrm{g} \mathrm{EGA} / \mathrm{mg} \mathrm{E})$ & $80.16 \pm 14.30$ \\
TFC $(\mu \mathrm{g} \mathrm{EQ} / \mathrm{mg} \mathrm{E})$ & $3.12 \pm 2.01$ \\
Tannins & $226.10 \pm 4.50$ \\
Chlorophylls $\mu \mathrm{g} / \mathrm{mL}$ & a: $6.10 \pm 50.62 \mathrm{~b}: 12.00 \pm 31.53$ \\
Carotenoid $\mu \mathrm{g} / \mathrm{mL}$ & $1.78 \pm 0.40$ \\
\hline
\end{tabular}




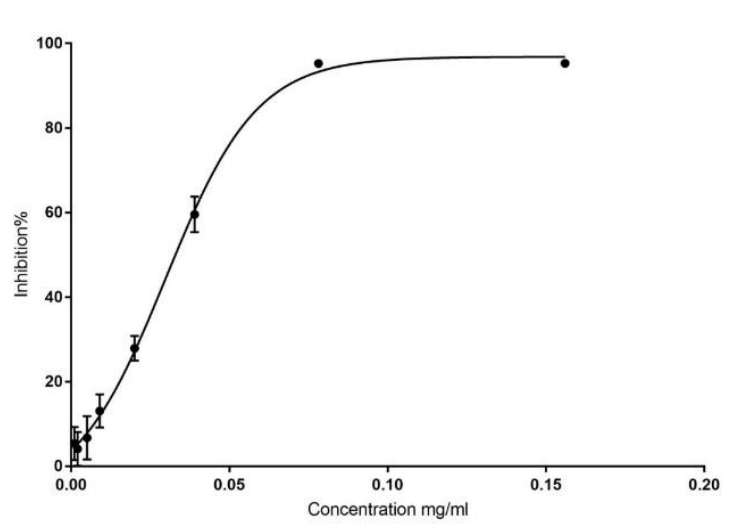

Figure 1. DPPH bleaching inhibition of Angelica archangelica aqueous extract

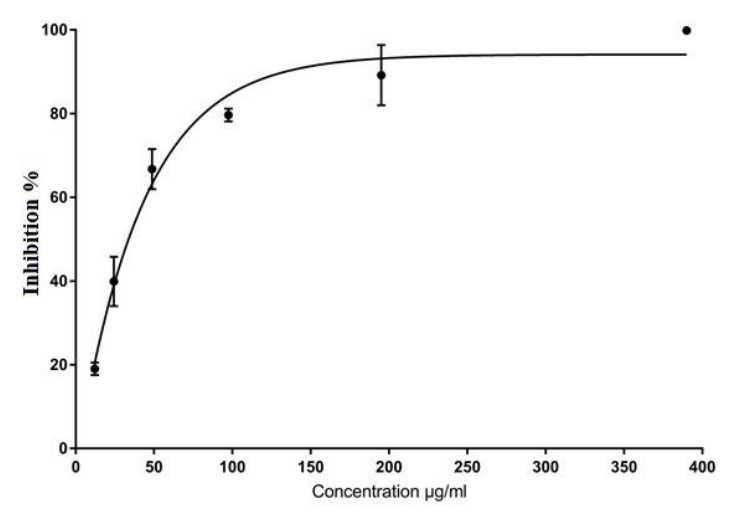

Figure 2. Ferrous ion chelating activity of $A$. archangelica aqueous extract

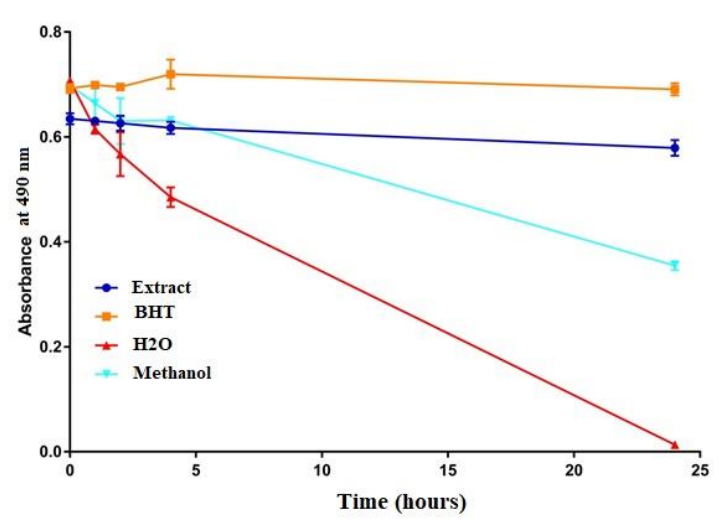

Figure 3. B carotene anti-bleaching activity of $A$. archangelica aqueous extract

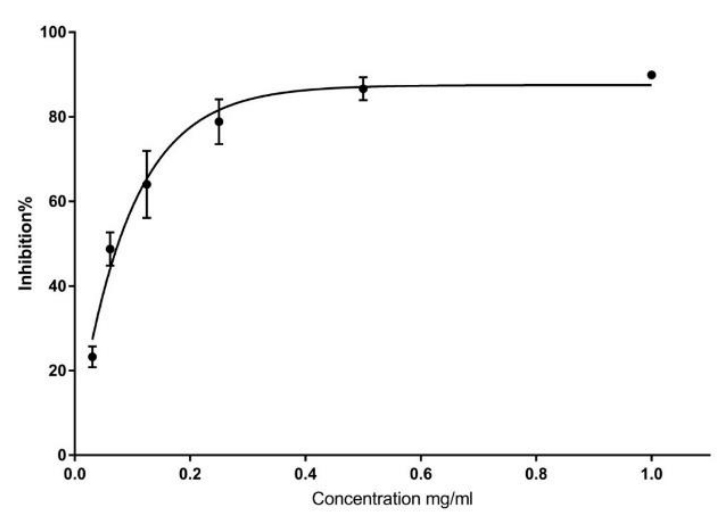

Figure 4. Albumine denaturation inhibitory effect of $A$. archangelica aqueous extract
Comparing our data with published literature is rather difficult because studies on the antioxidant activity of $A$. archangelica are minor almost unobtainable, however several, several studies showing the antioxidant effect of several varieties of the $A$. archangelica. The aqueous and ethanolic extracts of $A$. archangelica presents an antioxidant activity close to 80 and $20 \%$ respectively (100 $\mu \mathrm{g} / \mathrm{mg}$ ) (Heo and Lee, 2008). The activity protective against bleaching of $\beta$-carotene may be a result of the activity of plant compounds such as polyphenols and coumarins (Aminjafari et al., 2016).

\section{Anti-Inflammatory Activity}

Analgesic effect

In mice, the pain is manifested as abdominal cramps. From the results, $0.6 \%$ acetic acid was found to induce an average of 66.33 cramps counted after 25 minutes in the control lot. The aqueous extract of $A$. archangelica at a concentration of $200 \mathrm{mg} / \mathrm{kg}, 400 \mathrm{mg} / \mathrm{kg}$ and sodium Diclofenac $10 \mathrm{mg} / \mathrm{kg}$ reduce $(\mathrm{P}<0.05)$ the number of abdominal cramps; the percentages of inhibition were: $53.62 \%, 98.28 \%$ and $58.43 \%$ respectively (Figure 5). According to previous studies, analgesic activity extracts may be due to the presence of saponins, phenolic compounds or alkaloids (Kumar et al., 2011). The analgesic effect of these compounds is confirmed in several medicinal plants products like Aloe vera, Mentha peperita, Eucalyptus camaldulentis, Jesminum officinalus (Atta and Alkofahi, 1998). These components may have the ability to inhibit cyclooxygenesis - 1 and 5- lipooxygenase and / or inhibition of nerve transmission by the reabsorption blockade (Härmälä et al., 1992; Roos et al., 1997).

Anti-ulcer activity

The anti-ulcer effect of the aqueous extract of $A$. archangelica was determined. However, the oral administration of $70 \%$ ethanol to mice causes bleeding lesions extensive in the glandular part of the stomach. The formation of gastric lesions induced by ethanol, mice are orally administered the extract one hour before administration of the ulcerogenic agent at the dose tested (200 and $400 \mathrm{mg} / \mathrm{kg}$ ) (fig. 23). 70\% ethanol induces lesions on average $20.45 \pm 3.17 \%$. Pretreatment of mice by the aqueous extract 200, 400 and ranitidine $5 \mathrm{mg} / \mathrm{kg}$ decreases the percentage ulceration. This decrease was expressed as a very close protection percentage ( $\mathrm{P}>0.05) 86.55 \pm 3.51 \%$, $82.82 \pm 2.18 \%$ and $84.62 \pm 4.56 \%$ for the aqueous extract 200 , 400 and ranitidine $5 \mathrm{mg} / \mathrm{kg}$ respectively (Figure 6).

Studies on the protective effect of alcoholic root extract of $A$. archangelica with different doses ( 5 and $10 \mathrm{~mL} / \mathrm{kg}$ ) induces a protection of 30 and $80 \%$. This protection is due to decreased acid secretion and decreased pepsin activity and quantity leukotriene present in gastric juice even by the increase in the concentration of mucins and prostaglandins (Khayyal et al., 2001). Other study shows that polysaccharides extracted from Angelica sinensis induces a decrease in the surface area percentage of gastric ulcer induced by acetic acid and inhibits angiogenesis protects the stomach developed cancer (Ye et al., 2003). The mechanism of the onset of pain results from tissue damage responsible for increased release of many chemicals mediators such as histamine, prostaglandin, and serotonin, in the intravenous fluid peritoneal, which will stimulate the nociceptive receptors located at the peritoneal level. 


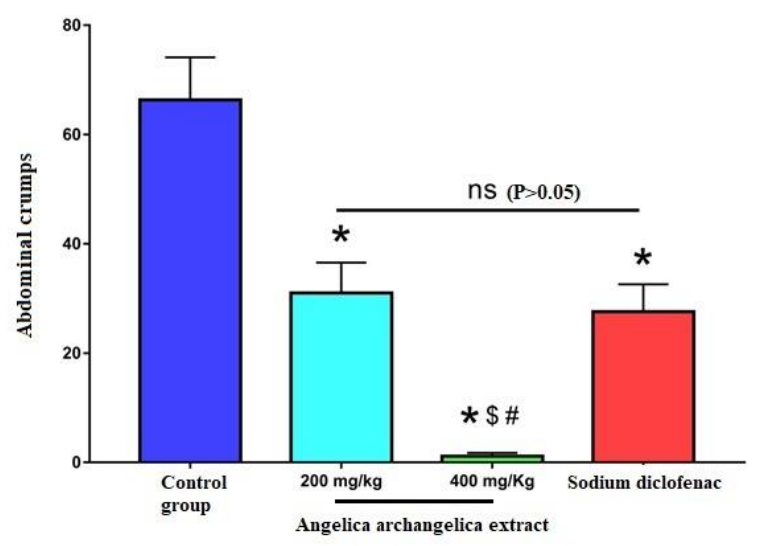

Figure 5. Analgesic effect of A. archangelica aqueous extract

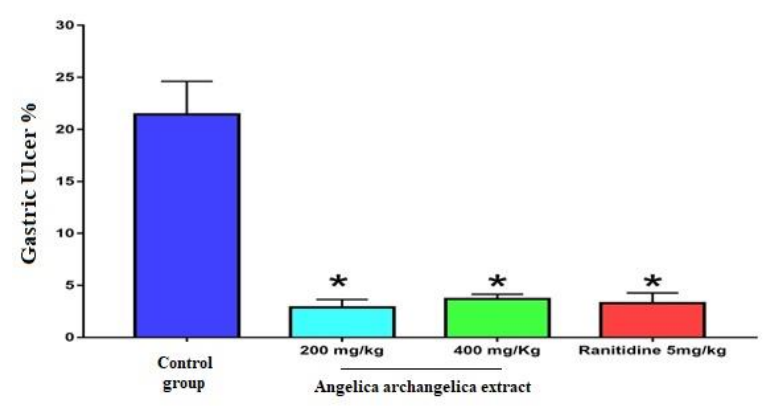

Figure 6. Anti-ulcer activity of $A$. archangelica aqueous extract

\section{Conclusion}

Aromatic and medicinal plants are an inexhaustible source of substances having a wide variety of biological and pharmacological activities. As part of this study, we were interested in the extraction, dosage, the study of the analgesic, antiulcer, anti-inflammatory and anti-oxidant properties of the aqueous extract of $A$. archangelica. These properties are probably related to the presence of polyphenols, flavonoids and tannins demonstrated by the phytochemical study carried out.

The antioxidant activity of the extracts has been evaluated by numerous in vitro tests; the results obtained confirm that the extract is endowed with a strong antioxidant power. The results obtained by the analgesic study showed that the extract has a significant analgesic activity.

In the anti-inflammatory activity, the results have shown that $A$. archangelica has a strong inhibitory effect on the denaturation of proteins causing inflammation. During this study we demonstrated the protective effect in vivo of the aqueous extract of $A$. archangelica against gastric ulcer induced by the ethanol. The treatment with the extract helps to provide protection against ulcer, which means that the extract has potent anti-ulcer activity. The extract of A. archangelica would therefore constitute an advantageous source of medicine. traditional improved very accessible and would be cheaper for the populations. For that he it is better to study other effects of this plant such as anti-inflammatory effect in vivo and to determine which are the pure molecules responsible for these biological effects.

\section{References}

Akgul H, Korkmaz N, Dayangaç A, Sevindik M. 2020. Antioxidant potential of endemic Salvia absconditiflora. Turkish Journal of Agriculture-Food Science and Technology, 8(10): 2222-2224. doi.org/10.24925/turjaf. v8i10.2222-2224.3697

Alhakmani F, Kumar S, Khan SA. 2013. Estimation of total phenolic content, invitro antioxidant and anti-inflammatory activity of flowers of Moringa oleifera. Asian Pacific journal of tropical biomedicine, 3 : 623-627. https://doi.org/ 10.1016/S2221-1691(13)60126-4

Aminjafari A, Miroliaei M, Angelova VT, Emamzadeh R, Djukic MM, Djuric A, Saso L. 2016. Antioxidant activity and protective role on protein glycation of synthetic aminocoumarins. Electronic Journal of Biotechnology, 19 : 43-48. https :// doi .org /10.1016/j.ejbt.2016.08.004

Atta A, Alkofahi A. 1998. Anti-nociceptive and antiinflammatory effects of some Jordanian medicinalplant extracts. Journal of ethnopharmacology, $60: 117-124$. https://doi.org/10. 1016/S0378-8741(97)00137-2

Barkun A, Leontiadis G. 2010. Systematic review of the symptom burden, quality of life impairment and costs associated with peptic ulcer disease. The American journal of medicine, 123(4): 358-366. https://doi.org/10.1016/j.amjmed.2009.09.031

Bouasla A, Bouasla I. 2017. Ethnobotanical survey of medicinal plants in northeastern of Algeria. Phytomedicine, 36: 68-81. https://doi.org/10.1016/j.phymed.2017.09.007

Benslama A, Harrar A. 2016. Free radicals scavenging activity and reducing power of two Algerian Sahara medicinal plants extracts. International Journal of Herbal Medicine, 4(6): 158161. DOI: 10.22271/flora.2016.v4.i6c.03

Benslama A, Harrar, A, Gul F, Demirtas I. 2017. Phenolic compounds, antioxidant and antibacterial activities of Zizyphus lotus L. leaves extracts. The natural products journal, 7(4): 316-322. DOI: 10.2174/221031550766 6170530090957

Benslama A, Daci S, Nabti L Z, Bendif H, Harrar A. 2021. Assessment of polyphenols contents, antibacterial and antioxidant activities of Origanum majorana extracts. European Journal of Biological Research, 11(4): 509-518. http://dx.doi.org/ 10.5281/zenodo.5608519

Bouzabata A. 2017. Les médicaments à base de plantes en Algérie: réglementation et enregistrement. Phytothérapie, 15 : 401-408. https://doi.org/10.1007/s10298-016-1089-5

Chauhan RS, Nautiyal MC, Cecotti R, Mella M, Tava A. 2016. Variation in the essential oil composition of Angelica archangelica from three different altitudes in Western Himalaya, India. Industrial crops and products, 94 : 401-404. DOI:10.1016/j.indcrop.2016.08.044

Decker EA, Welch B. 1990. Role of ferritin as a lipid oxidation catalyst in muscle food. Journal of Agricultural and Food Chemistry, 38: 674-677. https://doi.org/ 10.1021/jf00093 a019

Gharzouli K, Amira S, Gharzouli A, Khennouf S. 2002. Gastroprotective effects of honey and glucose-fructosesucrose-maltose mixture against ethanol-, indomethacin-, and acidified aspirininduced lesions in the rat. Experimental and Toxicologic Pathology, 54 : 217-221. https://doi.org/ 10.1078/0940-2993-00255

Gharzouli K, Gharzouli A, Amira S, Khennouf S. 1999. Prevention of ethanol-induced gastric lesions in rats by natural honey and glucose-fructose-sucrose-maltose mixture. Pharmacological Research, 39 : 151-156. https://doi.org/10.1006/phrs.1998.0420

Härmälä P, Vuorela H, Hiltunen R, Nyiredy S, Sticher O, Törnquist K, Kaltia S. 1992. Strategy for the isolation and identification of coumarins with calcium antagonistic properties from the roots of Angelica archangelica. Phytochemical Analysis, 3 : 42-48. https://doi.org/ $10.1002 /$ pca. 2800030108 
Heo JC, Lee SH. 2005. Amelioration of Asthmatic-Related Symptoms by an Aqueous Extract of Angelica archangelica L. Life Science. 18:1336-1341. 2008.Karila-Cohen P, Petit T, Teissier J and Merran S. Gastric ulcer. Journal de Radiologie, 86 (4): 387-391. DOI: 10.5352/JLS.2008.18.10.1336

Kartal N, Sokmen M, Tepe B, Daferera D, Polissiou M, Sokmen A. 2007. Investigation of the antioxidant properties of Ferula orientalis L. using a suitable extraction procedure. Food chemistry, 100: 584-589. https://doi.org/10.1016/j.foodchem. 2005.09.084

Khayyal MT, El-Ghazaly MA, Kenawy SA, Seif-El-Nasr M, Mahran LG, Kafafi YAH, Okpanyi SN. 2001. Antiulcerogenic effect of some gastrointestinally acting plant extracts and their combination. Arzneimittelforschung, 51 : 545-553. DOI: $10.1055 / \mathrm{s}-0031-1300078$

Kına E, Uysal İ, Mohammed FS, Doğan M, Sevindik M. 2021. In vitro antioxidant and oxidant properties of Centaurea rigida. Turkish Journal of Agriculture-Food Science and Technology, 9(10): 1905-1907. https://doi.org/10.24925/ turjaf.v9i10.1905-1907.4603

Korkmaz N, Dayangaç A, Sevindik M. 2021. Antioxidant, antimicrobial and antiproliferative activities of Galium aparine. Journal of Faculty of Pharmacy of Ankara University, 45(3): 554-564. Doi: 10.33483/jfpau.977776

Kumar D, Bhat ZA. 2012. Anti-anxiety activity of methanolic extracts of different parts of Angelica archangelica L. Journal of traditional and complementary medicine, $2: 235-241$. https://doi.org/10.1016/S2225-4110(16)30105-5

Kumar D, Bhat ZA, Kumar V, Chashoo I, Khan N, Shah M. 2011. Pharmacognostical and phytochemical evaluation of Angelica archangelica L. International Journal of Drug Development and Research, 3 (3): 173-188.

Kumar D, Bhat ZA, Shah M. 2012. Anti-anxiety activity of successive extracts of angelica archangelica linn. on the elevated t-maze and forced swimming tests in rats. Journal of Traditional Chinese Medicine, 32 : 423-429. https://doi.org/10.1016/S0254-6272(13)60049-7

Kylin M. 2010. Angelica archangelica $\mathrm{L}$. Thesis presented for the fulfillment of the requirements for the degree of Degree Project for BSc Thesis in Horticulture. Swedish University of Agricultural Sciences, 13. http://stud.epsilon.slu.se

Lacoste S. 2003. Les Plantes qui guérissent. DonnemarieDontilly (Seine-et-Marne): Ed. Repères-Santé. ISBN: 978-284939-000-9.

Li HB, Cheng KW, Wong CC, Fan KW, Chen F, Jiang Y. 2007. Evaluation of antioxidant capacity and total phenolic content of different fractions of selected microalgae. Food Chemistry, 102: 771-776. https://doi.org/10.1016/j.foodchem.2006.06.022

Li W, Huang H, Niu X, Fan T, Mu Q, Li H. 2013. Protective effect of tetrahydrocoptisine against ethanol-induced gastric ulcer in mice. Toxicology and applied pharmacology, $272: 21-29$. https://doi.org/10.1016/j.taap.2013.05.035

Lichtenthaler HK, Wellburn AR. 1983. Determinations of total carotenoids and chlorophylls a and b of leaf extracts in different solvents. Biochemical Society Transactions, 11(5): 591-592. DOI:10.1042/BST0110591

Lobiuc A, Zamfirache MM, Stratu A. 2012. Physiological aspects in two Angelica L. Taxa (Apiaceae). Analele Stiintifice ale
Universitatii" Al. I. Cuza" din Iasi, 58 (2) : 81-87.

Mustafa M, Menon J, Muiandy R, Fredie R, Sein M, Fariz A. 2015. Risk Factors, Diagnosis, and Management of Peptic ulcer Disease. IOSR Journal of Dental and Medical Sciences, 14 (7): 40-46.

Ommurugan B, Rao V. 2019. Pharmacotherapy of Peptic Ulcer Disease and Latest Research, Gastritis - New Approaches and Treatments, Bruna Maria Roesler, IntechOpen, 68625.

Padmanabhan P, Jangle SN. 2012. Evaluation of in-vitro antiinflammatory activity of herbal preparation, a combination of four medicinal plants. International Journal of Basic and Applied Medical Sciences, 2 : 109-116.

Pehlivan M, Mohammed FS, Şabik AE, Kına E, Dogan M, Yumrutaş Ö, Sevindik M. 2021. Some Biological activities of ethanol extract of Marrubium globosum. Turkish Journal of Agriculture-Food Science and Technology, 9(6): 1129-1132. DOI:https://doi.org/10.24925/turjaf.v9i6.1129-1132.4382

Perera N, Soysa P, Abeytunga T, Ramesha R. 2008. Antioxidant and cytotoxic properties of three traditional decoctions used for the treatment of cancer in Sri Lanka. Pharmacognosy Magasin, 4 : 172-181. http://hdl.handle.net/70130/101

Pincemail J, Bonjean K, Cayeux K, Defraigne JO. 2002. Mécanismes physiologiques de la défense antioxydante physiological action of antioxidant defences. Nutrition Clinique et Métabolisme, 16: 233- 239. https://doi.org/ 10.1016/S0985-0562(02)00166-8

Rajtar B, Skalicka-Woźniak K, Świątek Ł, Stec A, Boguszewska A, Polz-Dacewicz M. 2017. Antiviral effect of compounds derived from Angelica archangelica L. on Herpes simplex virus-1 and Coxsackievirus B3 infections. Food and Chemical Toxicology, 109: 1026-1031. https://doi.org/10. 1016/j.fct.2017.05.011

Roos G, Waiblinger J, Zschocke S, Liu J, Klaiber I, Kraus W, Bauer R. 1997. Isolation, identification and screening for COX-1-and 5-LO-inhibition of coumarins from Angelica archangelica. Pharmaceutical and Pharmacological Letters, 7: 157-160,

Sevindik M, Akgul H, Pehlivan M, Selamoglu Z. 2017. Determination of therapeutic potential of Mentha longifolia ssp. longifolia. Fresen Environ Bull, 26(7): 4757-4763.

Shekhar TC, Anju G. 2014. Antioxidant activity by DPPH radical scavenging method of Ageratum conyzoides Linn. leaves. American Journal of Ethnomedicine, 1 : 244-249, 2014.

Sipponen P, Maaroos HI. 2015. Chronic gastritis. Scandinavian Journal of Gastroenterology, 50 (6): 657-667. https://doi.org/ $10.3109 / 00365521.2015 .1019918$

Uysal İ, Mohammed FS, Şabik AE, Kına E, Sevindik M. 2021. Antioxidant and Oxidant status of medicinal plant Echium italicum collected from different regions. Turkish Journal of Agriculture-Food Science and Technology, 9(10): 19021904. https://doi.org/ 10.24925/turjaf.v9i10.1902-1904.4588

Ye Y, So H, Liu ESL, Shin V, Cho C. 2003. Effect of polysaccharides from Angelica sinensis on gastric ulcer healing. Life Sciences, 72: 925-932. https://doi.org/ 10.1016/S0024-3205(02)02332-9 